\title{
Panel estimating effects of macroeconomic determinants on tax revenue level in European Union
}

\author{
Article history: \\ Received: 5 August 2020 \\ Sent for revision: 22 October 2020 \\ Received in revised form: 29 October 2020 \\ Accepted: 1 November 2020 \\ Available online: 4 December 2020
}

\begin{abstract}
The level of tax revenue represents one of the most important issues for every country, especially in extraordinary circumstances. The aim of this paper is to identify which macroeconomic determinants are important to total tax revenue in order to determine which variables are the key generators of tax revenue collection. The subject of this research represents the estimating effects of selected macroeconomic determinants on total tax revenue in European Union countries from 2006 to 2018. Empirical analysis includes three panel regression models where total tax revenue, direct tax revenue and indirect tax revenue are determined as dependent variables. Results of fixed effects model show that $1 \%$ increase of GDP enhances total tax revenue for $6.91 \%$. Government expenditure, total investment and population have positive effect on total tax revenue where $1 \%$ increase of these determinants raise total tax revenue for $2.38 \%, 0.001 \%$ and $0.57 \%$ in these countries. Contrary, inflation, unemployment and gross national savings negatively affect the total tax revenue where their growth by $1 \%$ cause lower level of total tax revenue for $3.72 \%, 0.001 \%$ and $1.48 \%$. Likewise, gross domestic product and total investment lead to greater change of direct tax revenue and indirect tax revenue. Empirical findings show that governments
\end{abstract}

${ }^{1}$ University of Novi Sad, Faculty of Economics in Subotica,

branimir.kalas@ef.uns.ac.rs

2 University of Niš, Faculty of Economics

${ }^{3}$ University of Niš, Faculty of Economics

Industrija, Vol.48, No.3, 2020 
in EU countries should focus to higher GDP growth rate, greater level of government expenditure and total investment to enhance the total tax revenue level.

Keywords: taxes, macroeconomic determinants, European Union, panel data estimation.

\section{Panel procenjivanje efekata makroekonomskih determinanti na nivo poreskih prihoda u Evropskoj uniji}

Apstrakt: Nivo poreskih prihoda predstavlja jedno od najvažnijih pitanja za svaku zemlju, naročito u vanrednim okolnostima. Cilj ovog rada je identifikovati koje makroekonomske determinante su važne za ukupne poreske pirhode kako bi se utvrdilo koje varijable su ključni generatori prikupljanja poreskih prihoda. Predmet ovog istraživanja predstavlja procenjivanje efekata odabranih makroekonomskih determinanti na ukupne poreske prihode u Evropskoj uniji od 2006. do 2018. godine. Empirijska analiza uključuje tri panel regresiona modela gde su ukupni poreski prihodi, prihodi od direktnih poreza i prihodi od indirektnih poreza određeni kao zavisne varijable. Rezultati modela fiksnih efekata prikazuju da povećanje bruto domaćeg proizvoda od 1\% poboljšava ukupne poreske prihode za 6.91\%. Državni rashodi, ukupne investicije i populacija imaju pozitivne efekte na ukupne poreske prihode, pri čemu rast ovih determinanti od 1\% povećava ukupne poreske prihode za 2.38\%, 0.001\% i 0.57\% u posmatranim zemljama. Suprotno, inflacija, nezaposlenost $i$ ukupna štednja stanovništva negativno utiču na ukupne poreske prihode, gde njihov rast za $1 \%$ izaziva niži nivo ukupnih poreskih prihoda za $3.72 \%, 0.001 \%$ i 1.48\%. Takođe, bruto domaći proizvod i ukupne investicije dovode do veće promene prihoda od direktnih poreza i prihoda od indirektnih poreza. Empirijski nalazi pokazuju da bi se vlade u zemljama EU trebale fokusirati na veću stopu BDP rasta, viši nivo državnih rashoda $i$ ukupnih investicija kako bi poboljšale nivo ukupnih poreskih prihoda.

Ključne reči: porezi, makroekonomske determinante, zemlje EU, panel procena podataka

\section{Introduction}

Taxes are a powerful tool for any country that can be created in a way to contribute to more intensive growth and development of the economy. It implies that tax structure should be "friendly" to economic development where 
taxes, direct or indirect, cause positive implications on economic activity. The share of direct and indirect taxes has to be at the optimum level in order to provide lucrative effects to the economy. Castañeda Rodríguez (2018) emphasize that quantitative research on taxation is important in order to be able to test which determinants affect it and develop strategies to boost tax revenue and cover public expenditure. Andrejovska and Pulikova (2019) point out that taxes are important policy tool which significantly effects macroeconomic outcomes of tax policies (Andrejovska \& Pulikova, 2019). Grdinić et al. (2017) argue that it is important for the tax policy holders to determine potential effects that changes in individual tax forms will have on overall economic performance. Streimikiene et al. (2018) highlighted that revenue level should be an appropriate level to cover public needs and expenditure. By increasing tax revenue, government have ability to create maximum development projects for the public interest and to enhance infrastructure of health, education, as well as the quality of life of citizens. Lakatos and Karai (2020) indicate that ensuring a state budget balance has become a fundamental issue. Likewise, Stoilova (2017) points out that aim of taxation is not just collecting necessary funds to cover public expenditure but also contribution to economic stabilization, income distribution and resource allocation.

The structure of this research is as follows. After the introduction, there is a literature review on previous empirical studies that have examined the relationship between taxes and main macroeconomic determinants. The third section is methodology and data which includes defining variables, developing hypotheses and creating panel regression model. The fourth section contains descriptive and empirical analysis of total tax revenue, including direct tax revenue and indirect tax revenue in European Union countries for the period 2006-2018. This section includes different panel data estimation such as pooled ordinary least squares, fixed effects model and random effects model, as well as panel causality analysis. The last section summarizes the findings and conclusions, and provides informational support to governments in EU countries from the aspect of notifying macroeconomic determinants which are key generators for tax revenue level.

\section{Literature review}

There are many empirical studies that have estimated tax revenue and gross domestic product (Anastassiou and Dritsaki; 2005; Belullo and Dužman, 2011; Castro and Ramirez Camarillo, 2014; Kalaš et al., 2017; Loganathan et al., 2017; Stoilova, 2017; Andrašić et al., 2018; McNabb, 2018). Anastassiou and Drtiskai (2005) examined the relationship between tax revenue and gross 
domestic product in Greece for the period 1965-2020 and their empirical findings confirmed existence of causality between these variables in the observed period. Belullo and Dužman (2011) estimated the relationship between government revenues and gross domestic product in Croatia for the period 2000-2010. Empirical results have confirmed that GDP has a significant impact on changes in government revenues in Croatia. According to study of Castro and Ramirez Camarillo (2014), a country with high GDP per capita and low share of FDI is a country with more possibilities to have high tax revenue. Andrašić et al. (2018) showed that $1 \%$ increase of tax revenue enhances the gross domestic product for $0.29 \%$ in OECD countries from 1996 to 2016. Kalaš et al. (2017) confirmed a significant correlation between taxes and economic growth in Serbia meausred by gross domestic product growth rate. Szarowska (2013) identified significant and positive implications of indirect taxes on gross domsetic product growth rate in European Union for the period 1995-2010. Bajo-Rubion and Gomez-Plana (2015) identified that growth of direct taxes had a negative effect on gross domestic product and employment. Further, the impact of indirect taxes was milder, especially the effect of value added tax on employment. Đorđević et al. (2018) pointed out that indirect taxes have a significant place in developing EU countries. Daveri and Tabellini (2000) researched relationship between tax and unemployment in Europe for the period 1965-1995 and their empirical results confirmed positive nexus between these variables. Zortuk and Uzgoren (2008) showed that government expenditure had positive effect on taxes in Turkey in the short-run and long-run which implies that this economy finance greater consumption through higher level of tax burden. Stoilova nad Patonov (2012) analyzed tax structure in EU countries for the period 1996-2013 and they concluded that tax structure based on selective consumption taxes, personal income tax and tax on property was more stimulating to the economic growth. Hakim and Bujang (2011) reflected that tax revenue negatively affected the savings and investment in more than 100 countries for the period 1960-2009. Likewise, Paun (2019) argue that taxation contributed the gross domestic product growth and the attraction of foreign direct investment in CEE countries for the period 2005-2015.

\section{Research methodology}

The study includes annual data obtained from Eurostat database and International Monetary Fund Database (IMF) for twenty-seven countries in the European Union. This research includes panel data estimation of the effect of different macroeconomic determinants such as gross domestic product, inflation, unemployment, government expenditure, gross national savings, total investment and population was conducted for the period 2006-2018. 44 
Also, EMU variable is dummy variable included in panel regression analysis with moderation in order to provide information about effects of monetary union membership.

Table 1. Variable definition

\begin{tabular}{|c|c|c|c|c|}
\hline Variable & Notation & Calculation & Source & $\begin{array}{c}\text { Expected } \\
\text { effect }\end{array}$ \\
\hline \multicolumn{5}{|c|}{ Dependent variables } \\
\hline $\begin{array}{l}\text { Total tax } \\
\text { revenue }\end{array}$ & TT & $\%$ of GDP & Eurostat & \\
\hline $\begin{array}{l}\text { Direct tax } \\
\text { revenue }\end{array}$ & DT & $\%$ of GDP & Eurostat & \\
\hline $\begin{array}{l}\text { Indirect tax } \\
\text { revenue }\end{array}$ & IT & $\%$ of GDP & Eurostat & \\
\hline \multicolumn{5}{|c|}{ Independent variables } \\
\hline $\begin{array}{l}\text { Gross domestic } \\
\text { product }\end{array}$ & GDP & annual rate & IMF & + \\
\hline Inflation & INF & annual rate & IMF & - \\
\hline Unemployment & UNM & annual rate & IMF & - \\
\hline $\begin{array}{l}\text { Government } \\
\text { expenditure }\end{array}$ & GE & $\%$ of GDP & IMF & + \\
\hline $\begin{array}{c}\text { Gross national } \\
\text { savings }\end{array}$ & GNS & $\%$ of GDP & IMF & - \\
\hline Total investment & $\mathrm{TI}$ & $\%$ of GDP & IMF & + \\
\hline Population & POP & & Eurostat & + \\
\hline $\begin{array}{c}\text { European } \\
\text { Monetary union }\end{array}$ & EMU & $\begin{array}{c}0 \text { - non monetary } \\
\text { union } \\
1-\text { monetary } \\
\text { union }\end{array}$ & Eurostat & + \\
\hline
\end{tabular}

Source: Authors' illustration

The empirical research includes three models where total tax revenue, direct tax revenue and indirect tax revenue are defined as dependent variables for twenty-seven countries in the European Union. The study includes several hypotheses based on research's objectives that are defined as follows:

$\mathrm{H}_{1}$ : Higher GDP growth rate significantly increases total tax revenue in EU countries.

$\mathrm{H}_{2}$ : Higher level of inflation and unemployment significantly decreases total tax revenue in EU countries.

$\mathrm{H}_{3}$ : Government expenditure and total investment significantly enhances total tax revenue in EU countries.

$\mathrm{H}_{4}$ : Gross national savings significantly negatively affect the total tax revenue in EU countries. 
$\mathrm{H}_{5}$ : Population growth significantly increases total tax revenue in EU countries.

$\mathrm{H}_{6}$ : Macroeconomic determinants cause greater change of total tax revenue in countries that are not in Eurozone within the European Union.

The research includes different panel model estimation that covers time and space dimension. The fixed effect model was showed as an appropriate model in order to estimate effects of explanatory variables. It can be presented through three models:

Model I:

$T_{\mathrm{it}}=\alpha_{\mathrm{i}}+\beta_{1} \mathrm{GDP}_{\mathrm{it1} 1}+\beta_{2} I N F_{\mathrm{it} 2}+\ldots \beta_{3} U N M_{i t 3}+\beta_{4} \mathrm{GE}_{\mathrm{it} 4}+\beta_{5} \mathrm{GNS}_{\mathrm{it} 2}+\beta_{6} \mathrm{Tl}_{\mathrm{it}} \beta_{7} \mathrm{POP} \mathrm{P}_{\mathrm{it} 7}+\mu_{\mathrm{it}} ;(1)$

Model II:

$D T_{i t}=\alpha_{i}+\beta_{1} G_{D P} P_{i t 1}+\beta_{2} I N F_{i t 2}+\ldots \beta_{3} U N M_{i t 3}+\beta_{4} G_{i t 4}+\beta_{5} G N S_{i t 2}+\beta_{6} T_{l i t 6} \beta_{7} P O P_{i t 7}+\mu_{i t i} ;(1)$

Model III:

$I T_{i t}=\alpha_{i}+\beta_{1} G D P_{i t 1}+\beta_{2} I N F_{i t 2}+\ldots \beta_{3} U N M_{i t 3}+\beta_{4} G_{i t 4}+\beta_{5} G N S_{i t 2}+\beta_{6} T_{l_{i t 6}} \beta_{7} P O P i t 7+\mu_{i t} ; \quad(1)$

where TT - total tax revenue, DT - direct tax revenue, IT - indirect tax revenue, GDP - gross domestic product, INF - inflation, UNM unemployment, GE - government expenditure, GNS - gross national savings, $\mathrm{TI}$ - total investment, POP - population. Also, dummy variable EMU is included in terms of EMU - 0 (non monetary union) and EMU -1 (monetary union), $\mathrm{N}$ denotes number of observations, T number of period, $\alpha$ constant, $\beta$ parameters and $\mu$ random error.

\section{Empirical results}

This research includes descriptive statistics, panel unit root tests, as well as panel regression models such as pooled ordinary least squares, fixed effects model and random effects model. Finally, there are panel causality test in order to determine the potential relationship between macroeconomic determinants and selected tax variables. Before empirical analysis, there are taxation trends in European Union from 2006 to 2018 in terms of total tax revenue, direct tax revenue and indirect tax revenue. 
Figure 1. Total taxes in EU (\% GDP)

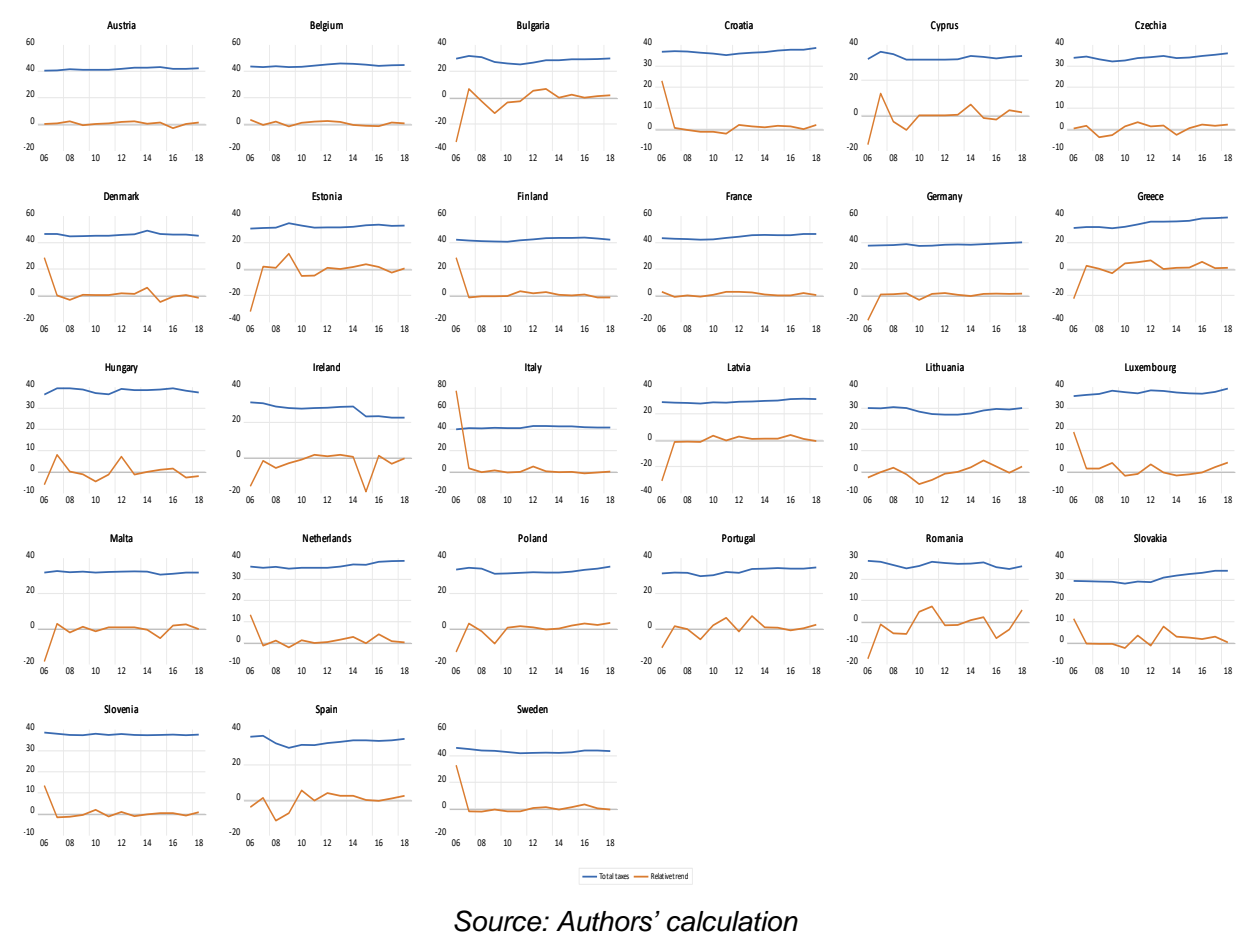

Figure 1 shows total tax revenue in EU countries in terms of their share in gross domestic product for the period 2006-2018. When analyzing by countries, it can be seen that Austria, Belgium, Denmark, Finland, France, Italy and Sweden recorded average value above $40 \%$ of gross domestic product. Economies such as Bulgaria, Ireland, Latvia, Lithuania and Romania had significantly lower share of total tax revenue (below $30 \%$ of gross domestic product). The highest average share is identified in Denmark where total tax revenue was $45.9 \%$ of gross domestic product, while Romania had the smallest total tax revenue $27.1 \%$ of gross domestic product at average level. Looking the difference rank from beginning to end of observed period, it can be concluded that Greece recorded the highest growth of $7.9 \%$ of gross domestic product, while share of total tax revenue mostly decreased in Ireland by $8.8 \%$ of gross domestic product during observed period. 
Figure 2. Direct and indirect taxes in EU (\% GDP)
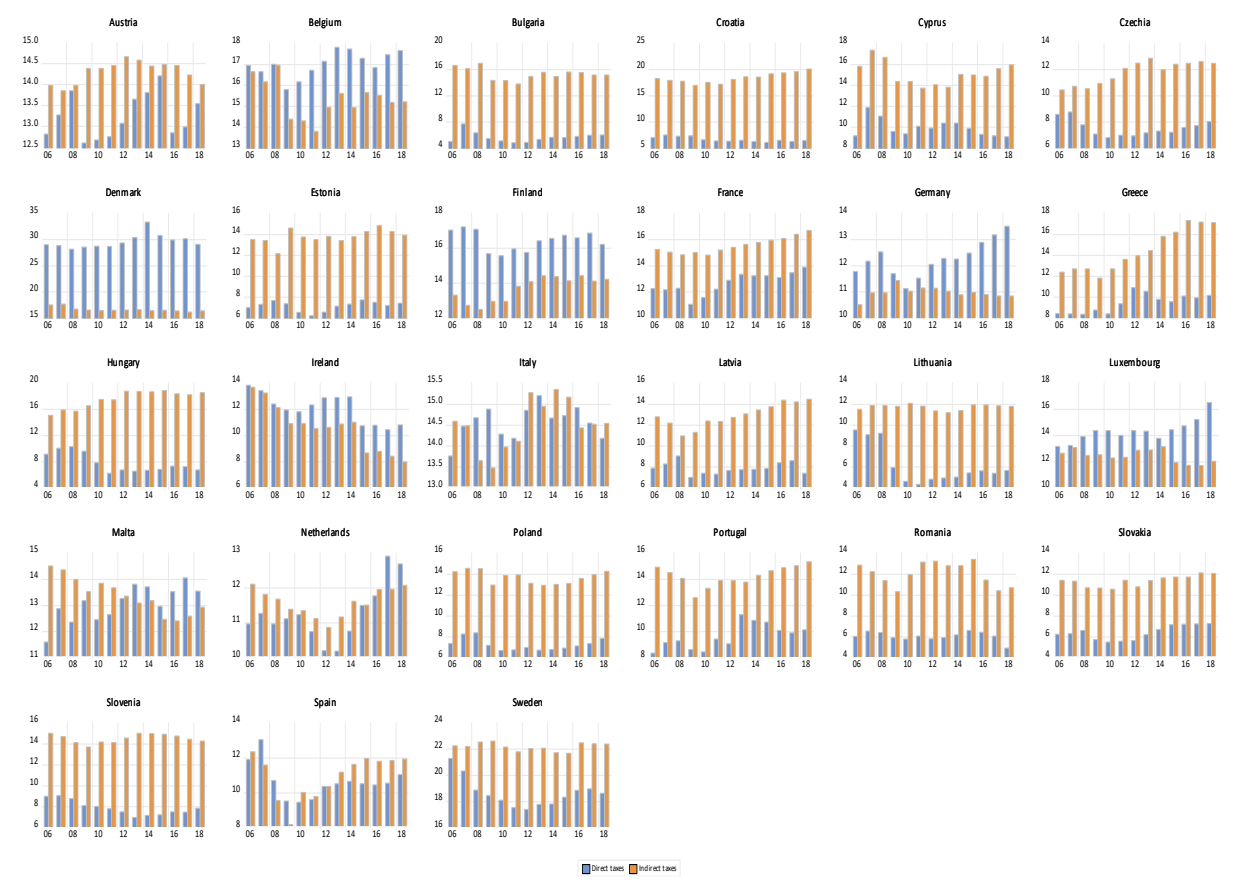

Source: Authors' calculation

After presenting total tax revenue, there are direct tax revenue and indirect tax revenue in EU countries in terms of their share in gross domestic product for the period 2006-2018. Denmark had the highest share of direct tax revenue at average level $(29.6 \%)$, while Sweden recorded highest average share of indirect tax revenue (22.5\%). On the other hand, Bulgaria and Romania had the smallest direct tax revenue compared to other EU countries, where their shares were $5.7 \%$ and $6.1 \%$ of gross domestic product. Further, indirect tax revenue at average level during observed period was the lowest in Ireland $(10.6 \%)$, Spain $(10.9 \%)$ and Germany $(11 \%)$. Looking the difference rank of direct tax revenue from beginning to end of analyzed period, it can be noticed that Luxembourg had the highest growth of direct tax revenue $2.8 \%$ of gross domestic product, while share of direct tax revenue mostly declined in Hungary and Lithuania by $3.6 \%$ of gross domestic product. At indirect tax revenue, Greece increased their share for $4.4 \%$ of gross domestic product, while share of indirect tax revenue mostly decreased in Ireland by $4.2 \%$ from 2006 to 2018. 
Table 2. Descriptive statistics

\begin{tabular}{|c|c|c|c|c|}
\hline Variable & Mean & Std. Dev. & Max & Min \\
\hline TT & 35.78 & 5.73 & 48.90 & 22.63 \\
\hline DT & 11.17 & 5.18 & 33.35 & 4.36 \\
\hline IT & 14.04 & 2.69 & 22.62 & 7.99 \\
\hline GDP & 1.91 & 3.85 & 25.01 & -14.81 \\
\hline INF & 1.95 & 2.16 & 15.25 & -1.68 \\
\hline UNM & 9.03 & 4.65 & 27.47 & 22.43 \\
\hline GE & 44.56 & 6.87 & 65.05 & 25.31 \\
\hline GNS & 22.11 & 5.39 & 34.28 & 51.38 \\
\hline TI & 22.57 & 4.62 & 41.54 & 10.22 \\
\hline POP & 16210 & 21.37 & 8290 & 0.405 \\
\hline $\begin{array}{l}\text { Number of } \\
\text { observations }\end{array}$ & \multicolumn{3}{|l}{351} & \\
\hline
\end{tabular}

Source: Authors calculation

Results of descriptive statistics show 351 observations where mean value of total tax revenue is $35.78 \%$ of gross domestic product for twenty-seven EU countries. Also, mean value of indirect tax revenue is $14.04 \%$ of gross domestic product that is greater compared to direct taxes in observed countries. The highest standard deviation is recorded at variable population which is logical because of greater differences in number of residents in EU market.

Table 3. Panel unit root test

\begin{tabular}{|c|c|c|c|c|}
\hline \multicolumn{5}{|c|}{ HO: Panels contain unit roots } \\
\hline \multicolumn{5}{|c|}{ H1: Panels are stationary } \\
\hline Variables & Number of panels & LLC test & IPS test & Hadri test \\
\hline TT & 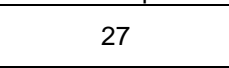 & $\begin{array}{c}-8.27 \\
(0.003)\end{array}$ & $\begin{array}{c}-2.06 \\
(0.020)\end{array}$ & $\begin{array}{c}7.33 \\
(0.000)\end{array}$ \\
\hline DT & 27 & $\begin{array}{l}-11.56 \\
(0.000)\end{array}$ & $\begin{array}{c}-2.25 \\
(0.012)\end{array}$ & $\begin{array}{c}7.66 \\
(0.000)\end{array}$ \\
\hline IT & 27 & $\begin{array}{c}-7.98 \\
(0.000)\end{array}$ & $\begin{array}{c}-1.94 \\
(0.026)\end{array}$ & $\begin{array}{c}8.03 \\
(0.000)\end{array}$ \\
\hline GDP & 27 & $\begin{array}{l}-15.93 \\
(0.000)\end{array}$ & $\begin{array}{l}-7.201 \\
(0.000)\end{array}$ & $\begin{array}{c}10.89 \\
(0.000)\end{array}$ \\
\hline INF & 27 & $\begin{array}{c}-7.01 \\
(0.000)\end{array}$ & $\begin{array}{c}-1.76 \\
(0.039)\end{array}$ & $\begin{array}{c}10.95 \\
(0.000) \\
\end{array}$ \\
\hline UNM & 27 & $\begin{array}{c}-2.98 \\
(0.001)\end{array}$ & $\begin{array}{c}-1.58 \\
(0.043)\end{array}$ & $\begin{array}{c}8.52 \\
(0.000)\end{array}$ \\
\hline GE & 27 & $\begin{array}{l}-11.33 \\
(0.000) \\
\end{array}$ & $\begin{array}{c}-2.62 \\
(0.004) \\
\end{array}$ & $\begin{array}{c}9.97 \\
(0.000) \\
\end{array}$ \\
\hline GNS & 27 & $\begin{array}{c}-9.13 \\
(0.000) \\
\end{array}$ & $\begin{array}{c}-2.15 \\
(0.016) \\
\end{array}$ & $\begin{array}{c}9.11 \\
(0.000) \\
\end{array}$ \\
\hline $\mathrm{TI}$ & 27 & $\begin{array}{c}-8.66 \\
(0.000) \\
\end{array}$ & $\begin{array}{c}-1.46 \\
(0.071) \\
\end{array}$ & $\begin{array}{c}10.06 \\
(0.000) \\
\end{array}$ \\
\hline POP & 27 & $\begin{array}{c}-8.69 \\
(0.000)\end{array}$ & $\begin{array}{c}-1.41 \\
(0.079)\end{array}$ & $\begin{array}{c}10.33 \\
(0.000) \\
\end{array}$ \\
\hline
\end{tabular}

Source: Authors calculation 
Results from Table 3 show that panel series are stationary at level of $5 \%$ and it enables the creation of different panel regression models such as pooled ordinary least squares, fixed effects model and random effects model.

Table 4. Panel Data Estimation - total tax revenue

\begin{tabular}{|c|c|c|c|c|c|c|}
\hline \multicolumn{7}{|c|}{ Model I } \\
\hline Variable & \multicolumn{2}{|c|}{ POLS } & \multicolumn{2}{c|}{ RE } \\
\hline TT & Coeff & Prob. & Coeff. & Prob. & Coeff. & Prob. \\
\hline GDP & 0.00155 & 0.000 & 6.91346 & 0.008 & 9.97211 & 0.000 \\
\hline INF & -0.00100 & 0.024 & -3.72012 & 0.014 & -1.53693 & 0.075 \\
\hline UNM & -0.00206 & 0.000 & -0.00117 & 0.001 & -0.00016 & 0.000 \\
\hline GE & 0.00727 & 0.000 & 2.38431 & 0.042 & 0.00025 & 0.000 \\
\hline GNS & -0.00285 & 0.000 & -1.47922 & 0.009 & -2.274401 & 0.041 \\
\hline TI & 0.00111 & 0.015 & 0.00126 & 0.002 & 0.00102 & 0.002 \\
\hline POP & 1.52342 & 0.021 & 0.56612 & 0.006 & 2.44931 & 0.001 \\
\hline EMU & 0.04693 & 0.082 & - & - & 0.46927 & 0.541 \\
\hline C & 2.33932 & 0.186 & 31.41235 & 0.000 & 26.03345 & 0.000 \\
\hline R-squared & 0.7807 & \multicolumn{2}{c|}{0.9448} & & 0.4928 \\
\hline $\begin{array}{c}\text { Model } \\
\text { specification }\end{array}$ & Chi-Sq. Stat & Chi-Sq. d.f. & & Prob \\
\hline $\begin{array}{c}\text { Hausman } \\
\text { test }\end{array}$ & 151.113 & 7 & & 0.000 \\
\hline
\end{tabular}

Source: Authors' calculation

Table 4 shows the impact of macroeconomic determinants on total tax revenue in EU countries through POLS, FE and RE models. Results of Hausman test confirmed that fixed model effect model is proper for analysis of macroeconomic determinants' effect on total tax revenue in observed period. Selected model explains $94.48 \%$ variations of independent variables and confirmed that all macroeconomic determinants have significant effect on total tax revenue in EU countries. Model results manifest that 1\% increase of GDP enhances total tax revenue for $6.91 \%$ which is the highest potential effect compared to other variables. Similarly, government expenditure, total investment and population have positive effect on total tax revenue where $1 \%$ increase of these determinants raise total tax revenue for $2.38 \%, 0.001 \%$ and $0.57 \%$. Contrary, inflation, unemployment and gross national savings negatively affect the total tax revenue where their growth by $1 \%$ cause lower level of total tax revenue for $3.72 \%, 0.001 \%$ and $1.48 \%$. These findings show that governments in these countries should focus on higher GDP growth rate and government expenditure to improve total tax revenue level. 
Table 5. Panel Data Estimation - direct tax revenue

\begin{tabular}{|l|c|c|c|c|c|c|}
\hline \multicolumn{7}{|c|}{ Model II } \\
\hline Variable & \multicolumn{2}{|c|}{ POLS } & \multicolumn{2}{c|}{ FE } & \multicolumn{2}{c|}{ RE } \\
\hline DT & Coeff & Prob. & Coeff. & Prob. & Coeff. & Prob. \\
\hline GDP & 0.00142 & 0.002 & 1.03442 & 0.001 & 1.42205 & 0.036 \\
\hline INF & -1.05443 & 0.093 & -3.45033 & 0.024 & -3.61316 & 0.022 \\
\hline UNM & -0.00026 & 0.000 & -3.89914 & 0.006 & -3.63772 & 0.078 \\
\hline GE & 0.00046 & 0.000 & 6.36663 & 0.077 & 2.82335 & 0.013 \\
\hline GNS & -0.00025 & 0.000 & -1.24431 & 0.056 & -7.86993 & 0.097 \\
\hline TI & 0.00014 & 0.016 & 7.27334 & 0.002 & 1.26841 & 0.053 \\
\hline POP & 2.32110 & 0.018 & 1.00338 & 0.007 & 3.73066 & 0.272 \\
\hline EMU & 0.27713 & 0.045 & - & - & 0.08756 & 0.957 \\
\hline C & \multicolumn{7}{|c|}{0.4809} & 5.78763 & 0.003 & 9.2967 & 0.000 \\
\hline R-squared & \multicolumn{7}{|c|}{0.9753} & & 0.3861 \\
\hline $\begin{array}{l}\text { Model } \\
\text { specification }\end{array}$ & Chi-Sq. Stat & Chi-Sq. d.f. & & Prob \\
\hline Hausman test & \multicolumn{2}{|c|}{7} & & 0.000 \\
\hline
\end{tabular}

Source: Authors' calculation

After estimating effects of macroeconomic determinants on total tax revenue, Table 5 and Table 6 separately show effects on direct taxes and indirect taxes in EU countries. Results of Hausman test confirmed that fixed model effect model is proper for analysis of macroeconomic determinants' effect on direct tax revenue in observed period. Selected model explains $97.53 \%$ variations of independent variables and confirmed that gross domestic product, government expenditure, total investment and population have positive effect on direct tax revenue. The level of inflation and unemployment negatively affect the direct tax revenue while gross national savings have no significant impact on direct tax revenue in EU countries. Model results reflect that $1 \%$ increases of gross domestic product and population enhance direct tax revenue for $1.03 \%$ and $1 \%$ government expenditure and total investment cause greater direct tax revenue level by $6.37 \%$ and $7.27 \%$. However, higher inflation and unemployment rate for $1 \%$ imply lower level of direct tax revenue in EU countries by $3.45 \%$ and $3.9 \%$ in the observed period. 
Table 6. Panel Data Estimation - indirect tax revenue

\begin{tabular}{|c|c|c|c|c|c|c|}
\hline \multicolumn{9}{|c|}{ Model III } \\
\hline Variable & \multicolumn{2}{|c|}{ POLS } & \multicolumn{2}{c|}{ FE } & \multicolumn{2}{c|}{ RE } \\
\hline DT & Coeff & Prob. & Coeff. & Prob. & Coeff. & Prob. \\
\hline GDP & 9.00123 & 0.007 & 6.53001 & 0.000 & 6.85445 & 0.000 \\
\hline INF & -8.42356 & 0.089 & -3.59042 & 0.023 & -3.48110 & 0.025 \\
\hline UNM & -1.45005 & 0.061 & -2.28003 & 0.028 & -2.58322 & 0.021 \\
\hline GE & 0.00021 & 0.000 & 2.87714 & 0.009 & 2.08113 & 0.313 \\
\hline GNS & -3.71006 & 0.880 & -5.78889 & 0.129 & -4.37071 & 0.040 \\
\hline TI & 1.60025 & 0.063 & 5.35551 & 0.011 & 5.05335 & 0.014 \\
\hline POP & 3.02105 & 0.000 & 3.61765 & 0.776 & 1.68864 & 0.353 \\
\hline EMU & 2.76229 & 0.000 & - & - & 2.79268 & 0.001 \\
\hline C & 7.32914 & 0.000 & 17.39506 & 0.000 & 17.63 & 0.000 \\
\hline R-squared & \multicolumn{2}{|c|}{0.4621} & 0.9053 & \multicolumn{2}{c|}{0.2674} \\
\hline $\begin{array}{c}\text { Model } \\
\text { specification }\end{array}$ & \multicolumn{2}{|c|}{ Chi-Sq. Stat } & \multicolumn{2}{c|}{ Chi-Sq. d.f. } & \multicolumn{2}{c|}{0.047} \\
\hline $\begin{array}{c}\text { Hausman } \\
\text { test }\end{array}$ & \multicolumn{2}{|c|}{14.228} & \multicolumn{2}{c}{} \\
\hline
\end{tabular}

Source: Authors' calculation

As with the previous models, results of Hausman test determined that fixed model effect model is an appropriate for analysis of macroeconomic determinants' effect on indirect tax revenue in the observed period. Selected model explains $97.53 \%$ of variations of independent variables and reflects that all macroeconomic determinants have significant impact on indirect tax revenue except gross national savings and population. Model results show that $1 \%$ increases of gross domestic product, government expenditure and total investment cause greater indirect tax revenue by $6.53 \%, 2.88 \%$ and $5.36 \%$. Contrary, $1 \%$ growth of inflation and unemployment declines indirect tax revenue for $3.59 \%$ and $2.28 \%$ for the observed period.

When analyzing EU countries from the aspect of monetary union membership, model results show that effects of selected macroeconomic determinants are greater in countries that are not in Eurozone for the observed period. Gross domestic product, government expenditure, total investment and population have significant and positive effect on total tax revenue which implies that their growth causes higher level of total tax revenue. Namely, changes of these determinants contribute to the greater change of total tax revenue in countries that are not in Eurozone (EMU=0). Inflation and unemployment have significant and negative effects on total tax revenue whereby growth of these determinants leads to lower total tax revenue, especially in countries that are not in Eurozone. By analyzing direct tax revenue and indirect tax revenue, it can be seen that their change mostly 
depends on the change of gross domestic product, inflation, unemployment, total investment and population. Namely, these determinants lead to greater change of direct tax revenue and indirect tax revenue, whereby countries that are in Eurozone $(E M U=1)$ are less exposed than countries that are not. Although monetary union status has positive implications to total tax revenue, countries that did not include euro as official currency have ability to focus on determinants that contribute to a higher level of tax revenue and create tax framework based on positively affected macroeconomic determinants such as gross domestic product, government expenditure and total investment. This way, governments will create space for more intensive growth supported by higher tax revenue.

Table 7. Panel Data Estimation with moderation EMU (0 - non monetary union, 1 - monetary union)

\begin{tabular}{|c|c|c|c|}
\hline Moderation - EMU & Total tax revenue & Direct tax revenue & Indirect tax revenue \\
\hline \multicolumn{4}{|c|}{ GDP } \\
\hline $\mathrm{EMU}=0$ & $\begin{array}{c}3.65697 \\
(0.000) \\
\end{array}$ & $\begin{array}{c}11.42054 \\
(0.000)\end{array}$ & $\begin{array}{c}16.12134 \\
(0.000)\end{array}$ \\
\hline $\mathrm{EMU}=1$ & $\begin{array}{c}.62231 \\
(0.000)\end{array}$ & $\begin{array}{c}11.36664 \\
(0.000)\end{array}$ & $\begin{array}{c}13.35907 \\
(0.000)\end{array}$ \\
\hline \multicolumn{4}{|c|}{ INF } \\
\hline $\mathrm{EMU}=0$ & $\begin{array}{c}-3.70313 \\
(0.000)\end{array}$ & $\begin{array}{c}-12.11206 \\
(0.000)\end{array}$ & $\begin{array}{c}-16.29133 \\
(0.000)\end{array}$ \\
\hline $\mathrm{EMU}=1$ & $\begin{array}{c}-3.65889 \\
(0.000)\end{array}$ & $\begin{array}{c}-11.90922 \\
(0.000)\end{array}$ & $\begin{array}{c}-13.49335 \\
(0.000)\end{array}$ \\
\hline \multicolumn{4}{|c|}{ UNM } \\
\hline$E M U=0$ & $\begin{array}{c}-3.79789 \\
(0.000)\end{array}$ & $\begin{array}{c}-13.89777 \\
(0.000)\end{array}$ & $\begin{array}{c}-15.64227 \\
(0.000)\end{array}$ \\
\hline$E M U=1$ & $\begin{array}{c}-3.78375 \\
(0.000)\end{array}$ & $\begin{array}{c}-13.40865 \\
(0.000)\end{array}$ & $\begin{array}{c}-12.87372 \\
(0.000)\end{array}$ \\
\hline \multicolumn{4}{|c|}{ GE } \\
\hline $\mathrm{EMU}=0$ & $\begin{array}{c}6.39704 \\
(0.000)\end{array}$ & $\begin{array}{c}7.65167 \\
(0.023)\end{array}$ & $\begin{array}{c}8.48521 \\
(0.002)\end{array}$ \\
\hline$E M U=1$ & $\begin{array}{c}5.69546 \\
(0.001)\end{array}$ & $\begin{array}{c}7.36258 \\
(0.014) \\
\end{array}$ & $\begin{array}{c}5.61347 \\
(0.003) \\
\end{array}$ \\
\hline \multicolumn{4}{|c|}{ GNS } \\
\hline $\mathrm{EMU}=0$ & $\begin{array}{c}-2.83856 \\
(0.012)\end{array}$ & $\begin{array}{c}-3.88849 \\
(0.068)\end{array}$ & $\begin{array}{c}-6.31445 \\
(0.054)\end{array}$ \\
\hline $\mathrm{EMU}=1$ & $\begin{array}{c}-2.87551 \\
(0.023) \\
\end{array}$ & $\begin{array}{c}-4.44137 \\
(0.094)\end{array}$ & $\begin{array}{c}-3.56172 \\
(0.071)\end{array}$ \\
\hline \multicolumn{4}{|r|}{10007} \\
\hline$E M U=0$ & $\begin{array}{c}4.10755 \\
(0.000)\end{array}$ & $\begin{array}{c}18.49761 \\
(0.002)\end{array}$ & $\begin{array}{c}14.06870 \\
(0.086)\end{array}$ \\
\hline $\mathrm{EMU}=1$ & $\begin{array}{c}4.04831 \\
(0.000) \\
\end{array}$ & $\begin{array}{c}15.24752 \\
(0.003)\end{array}$ & $\begin{array}{c}14.18153 \\
(0.071)\end{array}$ \\
\hline \multicolumn{4}{|c|}{ POP } \\
\hline $\mathrm{EMU}=0$ & $\begin{array}{c}3.49843 \\
(0.000)\end{array}$ & $\begin{array}{c}10.97018 \\
(0.000)\end{array}$ & $\begin{array}{c}16.16337 \\
(0.000)\end{array}$ \\
\hline $\mathrm{EMU}=1$ & $\begin{array}{c}3.44807 \\
(0.000)\end{array}$ & $\begin{array}{c}10.91162 \\
(0.000)\end{array}$ & $\begin{array}{c}13.50197 \\
(0.000)\end{array}$ \\
\hline
\end{tabular}

Source: Authors' calculation

Industrija, Vol.48, No.3, 2020 
Table 8. Dumitrescu Hurlin Panel Causality Test

\begin{tabular}{|c|c|c|c|c|}
\hline Direction & W-Stat. & Zbar-Stat. & Prob. & Causality \\
\hline $\mathrm{GDP} \rightarrow \mathrm{TT}$ & 3.585 & 1.486 & 0.045 & \multirow{2}{*}{ Unidirectional } \\
\hline $\mathrm{TT} \rightarrow \mathrm{GDP}$ & 3.533 & 0.543 & 0.593 & \\
\hline $\mathrm{INF} \rightarrow \mathrm{TT}$ & 3.498 & 0.498 & 0.618 & \multirow{2}{*}{ Unidirectional } \\
\hline $\mathrm{TT} \rightarrow \mathrm{INF}$ & 4.466 & 1.477 & 0.042 & \\
\hline $\mathrm{UNM} \rightarrow \mathrm{TT}$ & 3.029 & 1.029 & 0.077 & \multirow{2}{*}{ Unidirectional } \\
\hline $\mathrm{TT} \rightarrow$ UNM & 2.922 & 1.922 & 0.016 & \\
\hline $\mathrm{GE} \rightarrow \mathrm{TT}$ & 3.611 & 1.611 & 0.041 & \multirow{2}{*}{ Bidirectional } \\
\hline $\mathrm{TT} \rightarrow \mathrm{GE}$ & 4.797 & 2.797 & 0.043 & \\
\hline GNS $\rightarrow$ TT & 5.645 & 2.635 & 0.008 & \multirow{2}{*}{ Unidirectional } \\
\hline $\mathrm{TT} \rightarrow \mathrm{GNS}$ & 4.276 & 1.276 & 0.202 & \\
\hline $\mathrm{TI} \rightarrow \mathrm{TT}$ & 5.526 & 2.526 & 0.011 & \multirow{2}{*}{ Unidirectional } \\
\hline $\mathrm{TT} \rightarrow \mathrm{TI}$ & 2.560 & 0.439 & 0.660 & \\
\hline $\mathrm{POP} \rightarrow \mathrm{TT}$ & 5.416 & 2.415 & 0.015 & \multirow{2}{*}{ Bidirectional } \\
\hline $\mathrm{TT} \rightarrow \mathrm{POP}$ & 6.541 & 3.543 & 0.000 & \\
\hline
\end{tabular}

Source: Author' calculation

Table 8 presents causality results between total taxes and selected macroeconomic determinants in EU countries. Empirical results of DH test show bidirectional causality between total taxes and government expenditure, as well as total taxes and population. Furthermore, there is a unidirectional causality from gross domestic product to total taxes and from inflation to total taxes. In the same direction, there is a unidirectional causality between gross national savings and total investment to total taxes in EU countries. These results manifest that policymakers should focus on selected macroeconomic determinants in order to provide positive implications to total tax revenue in EU countries.

\section{Conclusions}

The research has estimated the effect of macroeconomic determinants on total tax revenue, including direct and indirect tax revenue in twenty-seven countries in the European Union for the period 2006-2018. Empirical analysis includes different panel models such as POLS model, FE model and RE model, as well as panel causality analysis, in order to precisely identify tax revenue determinants in selected countries. In this research, authors have examined the effect of gross domestic product, inflation, unemployment, government expenditure, gross national savings, total investment, population and EMU dummy variable on tax revenue in the observed period. Within selected models, Hausman test has reflected that FE model is adequate and it shows that $1 \%$ increase of GDP enhances total tax revenue for $6.91 \%$. Also, government expenditure, total investment and population have positive effect 
on total tax revenue where $1 \%$ increase of these determinants raise total tax revenue for $2.38 \%, 0.001 \%$ and $0.57 \%$. It means that hypotheses $\mathrm{H}_{1}, \mathrm{H}_{3}$ and $\mathrm{H}_{5}$ can be accepted, whereby gross domestic product, government expenditure and population have significant and positive effect on tax revenue. On the other side, inflation, unemployment and gross national savings negatively affect the total tax revenue where their growth by $1 \%$ causes lower level of total tax revenue for $3.72 \%, 0.001 \%$ and $1.48 \%$. It implies that $\mathrm{H}_{2}$ and $\mathrm{H}_{4}$ can be accepted, whereby these determinants have significant and negative effect on tax revenue. By analyzing countries that are in Eurozone and countries that are not, empirical results show that changes of macroeconomic determinants lead to smaller changes of tax revenues in countries that are in Eurozone during the observed period.

It implies that $\mathrm{H}_{6}$ can be accepted whereby effects of macroeconomic determinants on tax revenue are greater in countries that are not in Eurozone. Empirical results of $\mathrm{DH}$ test confirm bidirectional causality between total tax revenue and government expenditure as well as total tax revenue and population. Also, there is a unidirectional causality from gross domestic product to total tax revenue and from inflation to total tax revenue. Similarly, there is unidirectional causality between gross national savings and total investment to total tax revenue in EU countries. These findings show that policymakers should focus on selected macroeconomic determinants in order to provide positive implications to total tax revenues in EU countries. Finally, governments in these countries should focus on higher GDP growth rate, greater level of government expenditure and total investment to improve the total tax revenue level.

\section{References}

Anastassiou, T., \& Dritsaki, C. (2005). Tax Revenues and Economic Growth: An Empirical Investigation for Greece Using Causality Analysis. Journal of Social Sciences, 1(2), 99-104. doi: 10.3844/jssp.2005.99.104

Andrašič, J., Kalaš, B., Mirović, V., Milenković, N., \& Pjanić, M. (2018). Econometric modelling of tax impact on economic growth: Panel evidence from OECD countries. Economic Computation and Economic Cybernetics Studies and Research, 52(4), 211-226. doi: 10.24818/18423264/52.4.18.14

Andrejovska, A., \& Pulikova, V. (2019). Tax Revenues in the Context of Economic Determinants. Montenegrin Journal of Economics. 14(1), 133-141.

Bajo-Rubio, O., \& Gomez-Plana, A. (2015). Alternative strategies to reduce public deficits: Taxes vs Spending. Journal of Applied Economics, 18(1), 45-70.

Belullo, A., \& Dužman, T. (2011). Relations Among Government Revenues and Gross Domestic Product (GDP) of the Republic of Croatia. Economic Research Ekonomska Istraživanja, 24(4), 143-152. doi: 10.1080/1331677X.2011.115174 88 
Castañeda Rodríguez, V.M. (2018). Tax determinants revisited. An unbalanced data panel analysis. Journal of Applied Economics, 21(1), 1-24. doi: 10.1080/ 15140326.2018.1526867

Castro, G. Á., \& Ramírez Camarillo, D.B. (2014). Determinants of tax revenue in OECD countries over the period 2001-211. Contaduría y Administración, 59(3), 35-59. doi: 10.1016/S0186-1042(14)71265-3

Daveri, F., \& Tabellini, G. (2000). Unemployment, growth and taxation in industrial countries. Economic Policy, 15(30), 47-104.

Đorđević, M., Đurović-Todorović, J., \& Ristić, M. (2018). Improving performance of VAT system in developing EU countries: Estimating the determinants of the ratio C-Efficiency in the period 1997-2017. Facta Universitatis Series: Economics and Organization, 16(3), 239-254.

Grdinić, M., Drezgić, S., \& Blažić, H. (2017). An Empirical Analysis of the Relationship between Tax Structures and Economic Growth in CEE Countries. Ekonomicky časopis, 65(5), 426-447.

Hakim, T.A., Bujang, I. (2011). The Impact and Consequences of Tax Revenues' Components on Economic Indicators: Evidence from Panel Group Data. International Research Journal of Finance and Economics, 63, 99-116.

Kalaš, B., Milenković, I., Pjanić, M., Andrašić, J., \& Milenkovć, N. (2017). The Impact of Tax Forms on Economic Growth - Evidence from Serbia. Industry, 45(2), 113125.

Lakatos, M., \& Karai, E. (2020). After the first 32 years - new deal in Hungarian income taxation. The Annals of the Faculty of Economics in Subotica, 56(43), 117-134.

Loganathan, N., Taha, R., Ahmad, N., \& Subramaniam, T. (2017). Taxation, growth and the stock traded nexus in emerging Asian countries: heterogeneous and semi-parametric panel estimates. Economic Research - Ekonomska istraživanja, 30(1), 566-580. doi: 10.1080/1331677x.2017.1305789

McNabb, K. (2018). Tax Structures and Economic Growth: New Evidence from the Government Revenue Dataset. Journal of International Development, 30(2), 173-205. doi: 10.1002/jid.3345

Paun, D. (2019). Tax competition and factors influencing the gross domestic product and foreign direct investments of CEE countries. Economic ResearchEkonomska Istraživanja, 32(1), 876-893. doi:10.1080/1331677x.2019.1585896

Stoilova, D., \& Patonov, N. (2012). An empirical evidence for the impact of taxation on economy growth in the European Union. Book of Proceedings - Tourism and Management Studies International Conference Algarve.

Stoilova, D. (2017). Tax structure and economic growth: Evidence from the European Union. Contaduría y Administración, 62(3), 1041-1057. doi: 10.1016/j.cya.2017. 04.006.

Streimikiene, D., Ahmed, R.R., Vveinhardt, J., Ghauri, S.P., \& Zahid, S. (2018). Forecasting tax revenues using time series techniques - a case of Pakistan. Economic Research - Ekonomska istraživanja, 31(1), 722-754. doi: 10.1080/ 1331677X.2018.1442236

Szarowska, I. (2013). Effects of taxation by economic functions on economic growth in the European Union. MPRA Paper No. 59781, University of Library of Munich, Germany 
Zortuk, M., \& Uzgoren, N. (2008). The relationship between the taxation and government expenditure in Turkey - bounds test approach, Banks and Bank Systems, 3(1), 57-62.

Industrija, Vol.48, No.3, 2020 